\title{
Aerosol hygroscopicity in the marine atmosphere: a closure study using high-time-resolution, multiple-RH DASH-SP and size-resolved C-ToF-AMS data
}

\author{
S. P. Hersey, A. Sorooshian, S. M. Murphy, R. C. Flagan, and J. H. Seinfeld \\ Departments of Chemical Engineering and Environmental Science and Engineering, Caltech, Pasadena, CA 91125, USA
}

Received: 14 July 2008 - Published in Atmos. Chem. Phys. Discuss.: 4 September 2008

Revised: 17 November 2008 - Accepted: 24 March 2009 - Published: 7 April 2009

\begin{abstract}
We have conducted the first airborne hygroscopic growth closure study to utilize data from an Aerodyne compact Time-of-Flight Aerosol Mass Spectrometer (C-ToF-AMS) coupled with size-resolved, multiple-RH, high-time-resolution hygroscopic growth factor (GF) measurements from the differential aerosol sizing and hygroscopicity spectrometer probe (DASH-SP). These data were collected off the coast of Central California during seven of the 16 flights carried out during the MASE-II field campaign in July 2007. Two of the seven flights were conducted in airmasses characterized by continental origin. These flights exhibited elevated organic volume fractions $\left(\mathrm{VF}_{\text {organic }}=0.56 \pm 0.19\right.$, as opposed to $0.39 \pm 0.20$ for all other flights), corresponding to significantly suppressed GFs at high RH $(1.61 \pm 0.14$ at $92 \% \mathrm{RH}$, as compared with $1.91 \pm 0.07$ for all other flights), more moderate GF suppression at intermediate $\mathrm{RH}(1.53 \pm 0.10$ at $85 \%$, compared with $1.58 \pm 0.08$ for all other flights), and no measurable GF suppression at low RH $(1.31 \pm 0.06$ at $74 \%$, compared with $1.31 \pm 0.07$ for all other flights). Organic loadings were slightly elevated in above-cloud aerosols, as compared with below-cloud aerosols, and corresponded to a similar trend of significantly suppressed GF at high RH, but more moderate impacts at lower values of RH. A hygroscopic closure based on a volume-weighted mixing rule provided good agreement with DASH-SP measurements $\left(R^{2}=0.78\right)$. Minimization of root mean square error between observations and predictions indicated mission-averaged organic GFs of 1.22, 1.45, and 1.48 at 74,85 , and $92 \% \mathrm{RH}$, respectively. These values agree with previously reported values for water-soluble organics such as dicarboxylic and multifunctional acids, and correspond to a highly oxidized, presumably water-soluble,
\end{abstract}

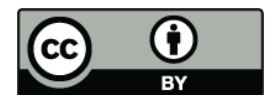

Correspondence to: J. H. Seinfeld (seinfeld@caltech.edu) organic fraction (mission-averaged $\mathrm{O}: \mathrm{C}=0.92 \pm 0.33$ ). Finally, a backward stepwise linear regression revealed that, other than RH, the most important predictor for GF is $\mathrm{VF}_{\text {organic }}$, indicating that a simple emperical model relating GF, $\mathrm{RH}$, and the relative abundance of organic material can provide accurate predictions $\left(R^{2}=0.77\right)$ of hygroscopic growth for the California coast.

\section{Introduction}

Atmospheric aerosols change size with fluctuations in relative humidity, with a magnitude dictated by chemical composition. Because this hygroscopic response determines particle size, it influences direct climate forcing attributed to aerosols. Further, subsaturated hygroscopic growth factor ( $D_{p \text {, wet }} / D_{p}$, dry $)$ is strongly correlated with $\mathrm{CCN}$ activity (Prenni et al., 2001). Given the importance of aerosol water uptake on both the direct and indirect light scattering properties of aerosols, incomplete understanding of aerosol hygroscopicity has been identified as a major limitation in estimations of climate forcing (IPCC, 2007).

With a firm foundational understanding of hygroscopic properties of inorganic aerosol constituents, there has been a significant shift in focus toward organic hygroscopicity in the last decade, as a number of theoretical (e.g., Clegg and Seinfeld, 2006; Topping et al., 2005a,b), laboratory (Peng et al., 2001; Choi and Chan, 2002a,b; Peng and Chan, 2001; Sjogren et al., 2007; Virkkula et al., 1999; Cruz and Pandis, 2000; Prenni et al., 2001, 2007, 2003; Cocker et al., 2001a,b; Hameri et al., 2002; Saathoff et al., 2003; Petters et al., 2006; Varutbangkul et al., 2006; Sjogren et al., 2007; Moore and Raymond, 2008; Rood et al., 1985; Carrico et al., 1998, 2000; Dougle et al., 1998; Magi and Hobbs, 2003; Kim et al., 2006; Kreisberg et al., 2001; Hegg et al., 2006;

Published by Copernicus Publications on behalf of the European Geosciences Union. 
Massling et al., 2007), and chamber (e.g., Ansari and Pandis, 2000; Cocker et al., 2001a,b; Duplissy et al., 2008) studies have sought to address how the presence of organics affects the water uptake characteristics of atmospheric aerosol. Despite advances in understanding of hygroscopic characteristics of organic-containing particles, measurements of aerosol hygroscopicity in field campaigns have remained relatively sparse.

Closure studies, which attempt to reconcile simultaneously measured hygroscopic and chemical data, link laboratory studies of hygroscopicity, theoretical models for water uptake, and field measurements of aerosol-water interactions. The standard method for predicting hygroscopic growth from composition data is based on volume-weighted water uptake by the individual chemical constituents. While it is usually possible to predict water uptake for the inorganic fraction of atmospheric aerosols, the wealth of organic species in the atmosphere, combined with limited understanding of organic aerosol hygroscopicity, has led investigators to assign the water uptake of organics as the particle growth not explained by inorganic constituents (e.g., Malm et al., 2005).

An important approach in hygroscopicity closure is to combine ambient measurements of water uptake with simultaneous, detailed chemical measurements from the Aerodyne Aerosol Mass Spectrometer (AMS). One notable groundbased study in an urban atmosphere (Gysel et al., 2007) used chemical data from the AMS to make volume-weighted predictions of hygroscopic growth factor (GF), providing good agreement between predicted and measured hygroscopicity values. Their study represents an improvement in the hygroscopic treatment of organics over prior work, but is limited by both low time resolution and single-RH conditions inherent in HTDMA systems.

The current study presents data obtained during seven flights in the marine atmosphere off the coast of Central California during the second Marine Stratus/Stratocumulus Experiment (MASE-II). The dataset is the first to combine hightime-resolution, size-resolved AMS chemistry with hightime-resolution, size-resolved hygroscopic data at multiple RH values from the Differential Aerosol Sizing and Hygroscopicity Spectrometer Probe (DASH-SP). Hygroscopic studies have previously been carried out in the marine atmosphere (see Table 1), but none of those listed utilized either AMS chemical data or hygroscopic data as highly size-, timeand RH-resolved as those presented here.

\section{Experimental}

\subsection{MASE-II Experiment}

The data presented here were obtained during a series of seven cloud probing flights carried out as part of the second Marine Stratus/Stratocumulus Experiment (MASE-II) field campaign during July 2007. The MASE-II experiment was the second of two airborne field campaigns directed toward measurement of aerosol-cloud relationships in marine stratocumulus in the Eastern Pacific Ocean. The Marine Stratus/Stratocumulus Experiment (MASE) was carried out in 2005 off the coast of Monterey, California (Lu et al., 2007), and MASE-II was undertaken in 2007 in the same region. Both experiments were carried out in the month of July, when marine stratocumulus are prevalent over the region, and utilized the CIRPAS Twin Otter aircraft. In each campaign, comprehensive airborne measurements were made of aerosol and cloud properties in areas both perturbed and unperturbed by continental emissions. Tables 2 and 3 list the flights carried out during MASE-II and the instrument payload onboard the Twin Otter, respectively. The present study addresses measurements of the hygroscopic properties of marine aerosols during MASE-II. Other flights probed emissions from a large bovine source and a large container ship, and these data are presented elsewhere (Sorooshian et al., 2008b; Murphy et al., 2009).

\subsection{Aerosol composition measurements}

Non-refractory aerosol chemical species were characterized by the Aerodyne compact Time-of-Flight Aerosol Mass Spectrometer (C-ToF-AMS) (Drewnick et al., 2004a,b). Particles with vacuum aerodynamic diameters $\left(D_{v a}\right)$ $50 \mathrm{~nm} \leq D_{v a} \leq 800 \mathrm{~nm}$ are focused by an aerodynamic lens, pass through a $3.5 \%$ chopper, and are vaporized at $530-$ $600^{\circ} \mathrm{C}$. The chopper is operated in three modes, to detect background mass spectra, ensemble average mass spectra over all particle sizes, or size-resolved mass spectra. After particle vaporization, molecules are ionized via electron impact, and are pulsed into a time-of-flight mass spectrometer. MASE-II data were collected at unit mass resolution. AMS mass spectra are deconvolved into sulfate, nitrate, ammonium, and organic mass loadings (Allan et al., 2004). O:C ratios are determined by using mass concentration at $m / z 44$ and a parameterization presented in Aiken et al. (2008).

AMS measurements were averaged to match the timeresolution of hygroscopicity measurements, and particle density was calculated for each flight leg. Because the CToF-AMS measures particle vacuum aerodynamic diameter $\left(D_{v a}\right)$ and the DMA measures electrical mobility diameter $\left(D_{e m}\right)$, one can determine particle density by comparing the volume distribution from the DMA $\left(d V / d \log \left(D_{e m}\right)\right)$ to the total mass distribution measured by the C-ToF-AMS $\left(d M / d \log \left(D_{v a}\right)\right)$ (DeCarlo et al., 2004). If one assumes that the aerosol consists of an internal mixture of spherical particles, the relationship between the two diameters is $\rho_{p}=\left(D_{v a} / D_{e m}\right) \rho_{o}$, where $\rho_{o}$ is unit density $\left(1 \mathrm{~g} / \mathrm{cm}^{3}\right)$. Under these assumptions, the ratio of the $D_{v a}$ where the mass distribution peaks to the $D_{e m}$ where the volume distribution peaks is the density. Reference to the peak of each distribution is given for simplicity, though in practice the ratio that causes the entirety of the two distributions to best align is 
Table 1. Previous marine aerosol hygroscopicity studies.

\begin{tabular}{llll}
\hline Investigators & Year & Study Area & Reported GFs \\
\hline Hegg & 1996 & Eastern Pacific & $1.4-2.0$ \\
Berg & 1998 & Pacific and Southern Oceans & $1.56-1.78$ \\
Kotchenruther & 1998 & Mid-Atlantic & $1.81-2.3^{*}$ \\
Gasso & 2000 & Eastern Atlantic & $\gamma=0.51-0.75^{* *}$ \\
Swietlicki & 2000 & Northeastern Atlantic & $1.6-1.8$ \\
Zhou & 2001 & Arctic Ocean & $1.4-1.9$ \\
Hegg & 2002 & Eastern Pacific & $\gamma=0.2-0.7^{* *}$ \\
Vakeva & 2002 & Northeastern Atlantic & $1.3-1.4^{* * *}$ \\
Massling & 2003 & Atlantic and Indian Oceans & $1.6-2.0$ \\
Hegg & 2006 & Eastern Pacific & $1.3-1.5$ \\
Kaku & 2006 & Eastern Pacific & $1.2-1.7$ \\
Tomlinson & 2007 & Southeastern Pacific & $1.3-1.7^{* * * *}$ \\
\hline
\end{tabular}

* Ratio of light scattering coefficient at $80 \% \mathrm{RH}$ to $30 \% \mathrm{RH}$.

** $\gamma$ from the expression $b_{s p}(R H) / b_{s p}\left(R H_{0}\right)=\left((1-R H / 100) /\left(1-R H_{0} / 100\right)\right)^{-\gamma}$ (Kasten, 1969).

*** Aitken mode particles.

**** $85 \%$ RH.

the final calculated particle density. Organic density is then calculated by using the bulk chemistry from the C-ToF-AMS for a given time period and assuming the particles measured by the DMA are completely dry. The dry densities of all the inorganic components are known and, assuming volume additivity, the density of the organic component can then be estimated. If the inorganic component of the particles measured by the DMA is not completely dry, this procedure will result in an underestimate of the particle density because the $D_{e m}$ will be larger than it would have been for a dry particle. Particles entering the C-ToF-AMS are assumed to be dry, and even if they are not completely devoid of water, the presence of small amounts of water causes little change in the vacuum aerodynamic diameter. One important issue concerning CToF-AMS data is the collection efficiency of particles within the instrument (Huffman et al., 2005). In this study, C-ToFAMS mass loadings were confirmed by comparison between the sulfate measurements from the C-ToF-AMS and the Particle Into Liquid Sampler - Ion Chromatograph (PILS-IC, Brechtel Mfg. Inc.) during periods when there were no rapid fluctuations in particulate mass loading. Composition data represent size-resolved AMS chemistry averaged over $10 \mathrm{~nm}$ size bins.

\subsection{Hygroscopicity measurements}

Hygroscopicity measurements were carried out with the Differential Aerosol Sizing and Hygroscopicity Spectrometer Probe (DASH-SP, Brechtel Mfg; Sorooshian et al., 2008a). Ambient particles pass through a nafion dryer before receiving a uniform charge distribution in a ${ }^{210} \mathrm{Po}$ neutralizer. A cylindrical, single-classification differential mobility analyzer (DMA) then size selects particles into narrow
Table 2. MASE-II flights.

\begin{tabular}{lll}
\hline $\begin{array}{l}\text { Flight } \\
\text { Number } \\
(\text { RF })\end{array}$ & $\begin{array}{l}\text { Date } \\
\text { (July 2007) }\end{array}$ & Type of Flight \\
\hline 1 & 10 & Cloud/aerosol interactions \\
2 & 11 & Cloud/aerosol interactions \\
3 & 12 & Bovine source probe \\
4 & 14 & Cloud/aerosol interactions \\
5 & 15 & Cloud/aerosol interactions \\
6 & 16 & Coordinated ship plume probe \\
7 & 21 & Cloud/aerosol interactions \\
8 & 22 & Cloud/aerosol interactions \\
9 & 23 & Cloud/aerosol interactions \\
10 & 24 & Cloud/aerosol interactions \\
11 & 25 & Cloud/aerosol interactions \\
12 & 26 & Cloud/aerosol interactions \\
13 & 28 & Cloud/aerosol interactions \\
14 & 29 & Cloud/aerosol interactions \\
15 & 30 & Bovine source probe \\
16 & 31 & Cloud/aerosol interactions \\
\hline
\end{tabular}

ranges of mobility-equivalent diameters $\left(D_{e m}\right)$ between 0.1 and $1.0 \mu \mathrm{m}$. The resulting monodisperse aerosol is split into five separate flows. One channel provides a redundant measurement of total particle concentration at the DMAselected size with a water condensation particle counter (TSI Model 3831). The remaining four channels consist of parallel nafion humidification chambers (Perma Pure, LLP, Model MD-070-24FS-4), followed by correspondingly humidified custom optical particle counters (OPCs). In the OPC sample volume, particles pass through a focused 
Table 3. MASE-II instrument payload.

\begin{tabular}{|c|c|c|c|c|}
\hline Parameter & Instrument & $\begin{array}{l}\text { Time } \\
\text { Resolution }\end{array}$ & Detection Limit & Size Range \\
\hline Particle Number Concentration & $\begin{array}{l}\text { Condensation Particle Counter } \\
\text { (TSI CPC 3010) }\end{array}$ & $1 \mathrm{~s}$ & $0-10000 \mathrm{~cm}^{-3}$ & $D_{p} \geq 10 \mathrm{~nm}$ \\
\hline $\begin{array}{l}\text { Particle Number Concentration } \\
\text { (including ultrafine) }\end{array}$ & $\begin{array}{l}\text { Condensation Particle Counter } \\
\text { (TSI CPC 3025) }\end{array}$ & $1 \mathrm{~s}$ & $0-100000 \mathrm{~cm}^{-3}$ & $D_{p} \geq 3 \mathrm{~nm}$ \\
\hline Aerosol Size Distribution & $\begin{array}{l}\text { Scanning differential mobility analyzer } \\
\text { (Dual Automated Classified Aerosol } \\
\text { Detector, DACAD) }\end{array}$ & $73 \mathrm{~s}$ & N/A & $10-700 \mathrm{~nm}$ \\
\hline Aerosol Size Distribution & $\begin{array}{l}\text { Passive Cavity Aerosol Spectrometer } \\
\text { Probe (PCASP) }\end{array}$ & $1 \mathrm{~s}$ & N/A & $0.1-2.6 \mu \mathrm{m}$ \\
\hline $\begin{array}{l}\text { Separation of Cloud Droplets } \\
\text { From Interstitial Aerosol }\end{array}$ & Counterflow Virtual Impactor & N/A & N/A & N/A \\
\hline Cloud Droplet Size Distribution & Phase Doppler Interferometer (PDI) & $1 \mathrm{~s}$ & N/A & 4-200 $\mu \mathrm{m}$ \\
\hline $\begin{array}{l}\text { Cloud and Drizzle Drop } \\
\text { Size Distribution }\end{array}$ & $\begin{array}{l}\text { Forward Scattering Spectrometer } \\
\text { Probe (FSSP) }\end{array}$ & $1 \mathrm{~s}$ & N/A & $1-46 \mu \mathrm{m}$ \\
\hline Cloud Droplet Liquid Water Content & $\begin{array}{l}\text { Light Diffraction } \\
\text { (Gerber PVM-100 probe) }\end{array}$ & $1 \mathrm{~s}$ & N/A & $5-50 \mathrm{~nm}$ \\
\hline $\begin{array}{l}\text { Aerosol Bulk Ionic Composition and } \\
\text { Soluble Organic Composition }\end{array}$ & Particle-Into-Liquid Sampler (PILS) & $5 \min$ & $0.02-0.28 \mu \mathrm{g} / \mathrm{m}^{3}$ & $1 \mu \mathrm{m}$ \\
\hline $\begin{array}{l}\text { Aerosol Bulk Composition } \\
\text { (non-refractory species) }\end{array}$ & $\begin{array}{l}\text { Aerodyne compact Time-of-Flight Aerosol } \\
\text { Mass Spectrometer (C-ToF-AMS) }\end{array}$ & $1 \mathrm{~s}$ or $15 \mathrm{~s}$ & $\leq 0.25 \mathrm{~g} / \mathrm{m}^{3}$ & $40 \mathrm{~nm} \leq D_{p}, v a \leq 1 \mu \mathrm{m}$ \\
\hline Aerosol Hygroscopicity & $\begin{array}{l}\text { Differential Aerosol Sizing and } \\
\text { Hygroscopicity Spectrometer } \\
\text { Probe (DASH-SP) }\end{array}$ & $15-100 \mathrm{~s}$ & N/A & $150 \mathrm{~nm} \leq D_{p} \leq 1 \mu \mathrm{m}$ \\
\hline Soot Absorption & $\begin{array}{l}\text { Photoacoustic Absoprtion } \\
\text { Spectrometer (PAS) }\end{array}$ & $1 \mathrm{~s}$ & $1 \mathrm{Mm}^{-1}$ & $10 \mathrm{~nm}-5 \mu \mathrm{m}$ \\
\hline Soot Absorption & $\begin{array}{l}\text { Particle Soot Absorption } \\
\text { Photometer (PSAP) }\end{array}$ & $\geq 1 \mathrm{~s}$ & N/A & N/A \\
\hline
\end{tabular}

laser beam $(\lambda=532 \mathrm{~nm}$, World Star Technologies, Model TECGL-30) and scatter light in proportion to size $\left(D_{p}\right)$ and refractive index (RI). Forward-scattered light is collected and focused on a photomultiplier tube, and the resulting electrical pulse is recorded by a high-speed data acquisition computer. An iterative data processing algorithm, based on laboratory calibrations with salts of known refractive indices, is used to determine the best fit on a solution surface relating electrical pulse height, size, and refractive index. The hygroscopic growth factor $\left(\mathrm{GF}=D_{p}\right.$, wet $/ D_{p}$, dry $)$ is corrected for the RI change caused by particulate liquid water at elevated RH. Temperature and pressure measurements are continually made at multiple locations in the instrument, and used to ensure that temperature and pressure variability do not impact hygroscopicity measurements.

In the current study, hygroscopicity was measured at dry sizes corresponding to $D_{e m}$ of 150,175 , and $200 \mathrm{~nm}$. Multiple RH sensors in the nafion tubes and OPCs controlled RHs to dry $(\leq 8 \%), 74 \%, 85 \%$, and $92 \%$, with $\mathrm{RH}$ uncertainty of $1.5 \%$. Low particle loadings inherent in the marine atmosphere required increased on-line collection times at each DMA size step, but usually $\leq 1$ min was sufficient to overcome counting statistic limitations. Overall uncertainty in GF calculations is $4.5 \%$.
Assuming particles to be uniform, non-light-absorbing spheres allows the assumption that the intensity of scattered light is a function of only $\mathrm{RI}$ and $D_{p}$. This assumption also allows calculation of dry, "effective" RI from the known DMA-selected $D_{p}$ and measured scattered light intensity.

\subsection{Hygroscopic closure}

A volume-weighted mixing rule was used to perform a hygroscopic closure using AMS and DASH-SP data, under the assumption of independent and additive water uptake by individual constituents in each particle:

$\operatorname{GF}_{\text {mixed }}\left(a_{w}\right)=\left(\sum_{i} \epsilon_{i} \operatorname{GF}_{i}\left(a_{w}\right)^{3}\right)^{1 / 3}$

where $\mathrm{GF}_{\text {mixed }}$ is the overall particle GF, $a_{w}$ is the water activity, $\mathrm{GF}_{i}$ is the hygroscopic growth factor for pure species $i$, and $\epsilon_{i}$ is the volume fraction of species $i$. At equilibrium, $a_{w}=\mathrm{RH}$ (Seinfeld and Pandis, 2006). Values for $\epsilon_{i}$ were calculated for the following species, using AMS masses of ammonium $\left(\mathrm{NH}_{4}^{+}\right)$, nitrate $\left(\mathrm{NO}_{3}^{-}\right)$, sulfate $\left(\mathrm{SO}_{4}^{2-}\right)$, and total organic: ammonium nitrate $\left(\mathrm{NH}_{4} \mathrm{NO}_{3}\right)$, ammonium sulfate $\left(\left(\mathrm{NH}_{4}\right)_{2} \mathrm{SO}_{4}\right)$, ammonium bisulfate $\left(\mathrm{NH}_{4} \mathrm{HSO}_{4}\right)$, sulfuric acid $\left(\mathrm{H}_{2} \mathrm{SO}_{4}\right)$, and organic. Partitioning between sulfate 
species was determined on the basis of the ammonium to sulfate molar ratio $\left.\left(\mathrm{SR}=\left[\mathrm{NH}_{4}^{+}\right] / \mathrm{SO}_{4}^{2-}\right]\right)$. When $\mathrm{SR} \leq 1$, the sulfate was assumed to be a mixture of $\mathrm{H}_{2} \mathrm{SO}_{4}$ and $\mathrm{NH}_{4} \mathrm{HSO}_{4}$; when $1<\mathrm{SR}<2$, sulfate was assumed to be a mixture of $\mathrm{NH}_{4} \mathrm{HSO}_{4}$ and $\left(\mathrm{NH}_{4}\right)_{2} \mathrm{SO}_{4}$; when $\mathrm{SR} \geq 2$, sulfate was assumed to be solely $\left(\mathrm{NH}_{4}\right)_{2} \mathrm{SO}_{4}$. During MASE-II, sulfate was predominantly found to exist as $\mathrm{NH}_{4} \mathrm{HSO}_{4}$. $\left(\mathrm{NH}_{4}\right)_{2} \mathrm{SO}_{4}$ is assumed to have a GF of unity at RH equal to $74 \%$ since particles are exposed to RH well below its effloresence point before subsequent rehumidification. The organic fraction was assumed to be hydrophilic, based on evidence of a high degree of organic oxygenation from AMS mass spectra (see Sect. 3.3). Values of $\mathrm{GF}_{i}$ for the organic fraction were calculated as those necessary to minimize the root mean square error in comparing predictions with measured hygroscopicity.

\section{Results}

GF values for seven flights are presented (RF 7, 10, 11, $12,13,14$, and 16 in Table 2). Table 4 presents measured GFs at each RH and each $D_{e m}$, dry. Typically, multiple measurements were made on each leg, at each size, for each flight. The error reported is \pm one standard deviation in these multiple measurements. When only one measurement was made at a given size in a given leg, it is reported without error. Ship plumes were encountered on flights 10 and 16 , as evidenced by brief, significantly elevated particle number concentration. Analysis of GF measurements in these presumptive plumes is not presented in the present work. Aerosol densities were calculated for each leg and used in the analysis below. Mission-averaged densities (averaged over all flight legs) were found to be $1.53 \pm 0.19,1.56 \pm 0.20$, and $1.47 \pm 0.15 \mathrm{~g} / \mathrm{cm}^{3}$ for below-cloud, above-cloud, and free troposphere legs, respectively. Mission-averaged organic densities were calculated to be $1.20 \pm 0.76,1.34 \pm 0.46$, and $1.30 \pm 0.24$ for below-cloud, above-cloud, and free troposphere legs, respectively.

\subsection{Airmass origin}

Relative to the other flights, RF 12 and 16 exhibited significantly suppressed water uptake at high RH for all dry sizes. During these two flights, $92 \%$ GF values for $200 \mathrm{~nm} D_{e m}$, dry particles averaged $1.61 \pm 0.14$, as compared with $1.91 \pm 0.07$ for all other flights. These low-GF flights corresponded to significantly elevated total organic, as measured by the AMS. Mass concentration averaged $1.97 \pm 1.71 \mu \mathrm{g} / \mathrm{m}^{3}$ organic (as opposed to $0.58 \pm 0.63 \mu \mathrm{g} / \mathrm{m}^{3}$ for all other flights), corresponding to volume fraction organic $\left(\mathrm{VF}_{\text {organic }}\right)$ of $0.56 \pm 0.19$ (as opposed to $0.39 \pm 0.20$ for all other flights).

Back-trajectory analysis suggests that the MASE-II flights can be categorized by airmass origin as either polluted/continental (flights 12, 16), or non-continentally influenced (flights $7,10,11,13,14)$. Figure 1 shows
92\% GF measurements for $200 \mathrm{~nm} D_{e m}$, dry particles, with corresponding 48-h HYSPLIT (available at: http://www. arl.noaa.gov/ready/hysplit4.html) back-trajectories identifying airmass origin. Note that the low GFs and high $\mathrm{VF}_{\text {organic }}$ measured on flights 12 and 16 correspond with airmass origins over the continental United States, while higher GFs and lower $\mathrm{VF}_{\text {organic }}$ measured on other flights correspond to airmass origins over the clean marine environment. It is interesting to note that trajectories at sea level have marine origins for all flights (including low-GF flights 12 and 16), and that there is a general trend of descending air from aloft over the course of the trajectories. This suggests that mixing of air from aloft is a significant factor in determining aerosol characteristics in the marine boundary layer. It is also noteworthy that GF values at low RH were not significantly suppressed, with values of $1.31 \pm 0.06$ at $74 \%$ (compared with $1.31 \pm 0.07$ for all other flights). GF values at intermediate RH were moderately suppressed in the continental airmasses, measuring $1.53 \pm 0.10$ at $85 \%$ (compared with $1.58 \pm 0.08$ for all other flights). In other words, the effect of the high- $\mathrm{VF}_{\text {organic }}$, continental airmass was to significantly suppress GF at high RH, while having no measurable effect on aerosol water uptake at low RH and a moderate impact at intermediate RH. These results, while suggestive of continental airmass influence, should be interpreted in light of the relatively coarse grid resolution of the HYSPLIT model. In this analysis, small shifts in back-trajectories toward continental origin correlate with significantly suppressed high-RH GFs.

\subsection{Hygroscopicity trends}

No size-dependent hygroscopicity was observed over the range of measured $D_{e m}$, dry, and in addition, no significant size-dependent trends in $\mathrm{VF}_{\text {organic }}$ were observed. Further, organic-to-sulfate ratios from the AMS showed no significant variation over the size range measured by the DASH-SP. This suggests an internally-mixed aerosol between dry sizes of 150 and $200 \mathrm{~nm}$.

Figure 2 shows below- and corresponding above-cloud 92\% GF values for all flights. There exists a ubiquitous trend of higher below-cloud aerosol GF values at high RH when compared with top of cloud hygroscopicity values ( $1.88 \pm 0.14$ below cloud, versus $1.78 \pm 0.18$ above cloud). Marker sizes, proportional to $\mathrm{VF}_{\text {organic }}$, suggest a trend of higher organic loading above cloud in several flights $(0.36 \pm 0.15$ below cloud, versus $0.43 \pm 0.22$ above cloud). While variability is rather large in these measurements, the trend of elevated $\mathrm{VF}_{\text {organic }}$ above-cloud does correspond to suppressed GF at high RH. There is a trend of more moderate GF suppression at intermediate RH in the higher $\mathrm{VF}_{\text {organic }}$ above-cloud layer ( $1.53 \pm 0.06$ above cloud, as compared with $1.58 \pm 0.07$ below cloud). Unlike the continentalinfluenced flights, there is evidence of greater suppression of low-RH GFs in above-cloud legs, with 74\% GF values of 
$1.31 \pm 0.05$ above cloud, compared with $1.36 \pm 0.05$ below. It appears, then, that the elevated organic loadings typical of above-cloud legs are correlated with GF suppression at high $\mathrm{RH}$, and more moderate GF suppression at lower RHs.

\subsection{Hygroscopic closure}

A hygroscopic closure was performed, using volumeweighted hygroscopic contributions from each chemical constituent identified by the AMS. O:C ratios for the flights presented were very similar for below-cloud $(0.93 \pm 0.32)$, above-cloud $(0.91 \pm 0.26)$, and free troposphere $(0.92 \pm 0.25)$ legs in both continentally- $(0.94 \pm 0.30)$ and marine-influenced $(0.91 \pm 0.25)$ flights. This result indicates that the organic component was consistently highly oxidized. With this evidence, the organic fraction was treated as a bulk, water-soluble constituent and was not divided into soluble and insoluble fractions based on AMS organic mass spectra (Kondo et al., 2007). As described in Sect. 2.4, GF values were calculated for the organic component of the aerosol by minimizing root mean square error when comparing measured GFs with volume-weighted closure predictions. Mission-averaged organic GFs were determined to be $1.22,1.45$, and 1.48 at 74,85 , and $92 \% \mathrm{RH}$, respectively. Agreement at 74 and $92 \% \mathrm{RH}$ is within 2\%, compared with the hydrophilic multifunctional and dicarboxylic acids parameterized in Peng et al. 2001, though the $85 \%$ organic GF is overpredicted here by $7 \%$. Closure results are presented in Fig. 3. Markers in Fig. 3 are color-coded according to relative humidity, and marker size is proportional to $\mathrm{VF}_{\text {organic. }}$ The volume-weighted hygroscopic closure utilizing size-resolved AMS chemistry achieves good agreement with the 675 DASH-SP GF measurements, with an $R^{2}$ of 0.78 . Agreement is better at lower values of $\mathrm{RH}$, owing to smaller GF magnitudes and less overall GF variability.

Aside from the obvious RH dependence of GF values, the clearest trend in Fig. 3 is that of larger markers (higher $\mathrm{VF}_{\text {organic }}$ ) at low GF transitioning to smaller markers (lower $\mathrm{VF}_{\text {organic }}$ ) at high values of GF for the same RH. The clarity and regularity of this trend reveal the importance of the organic fraction in determining GF values.

\subsection{Simplified parameterization}

To further investigate the relative importance of each parameter in quantifying aerosol water uptake, and to detemine the simplest empirical model still capable of accurately predicting GF, a backward stepwise linear regression was performed. The process, which eliminates predictors oneby-one to generate increasingly simplified linear representations of data, started with over 60 predictors, ranging from PILS and AMS chemical parameters to atmospheric data. The result is a two-parameter model that predicts GF as a function of $\mathrm{RH}$ and $\mathrm{VF}_{\text {organic }}$ :

$$
\mathrm{GF}=-0.312+0.0233(\mathrm{RH})-0.282\left(\mathrm{VF}_{\text {organic }}\right)
$$

Figure 4 demonstrates the accuracy with which this model predicts DASH-SP GF values over the measured the range of $\mathrm{RH}$ and $\mathrm{VF}_{\text {organic }}$. It is noteworthy that the $R^{2}$ for this model is 0.77 , indicating that the simple, two-parameter model explains only $1 \%$ less variability than the full volume-weighted chemical closure, which contains significantly more information (i.e. multiple inorganic chemical species and their individual GFs, in addition to organic fraction with its associated GF). It appears as though accurate predictions of particle water uptake in this region can be made simply on the basis of relative humidity and the relative abundance of organics in the aerosol, given a relatively uniform, highly-oxidized organic component internally mixed with predominantly ammonium bisulfate. While this model accurately predicts GF over the range of $\mathrm{RH}$ and $\mathrm{VF}_{\text {organic }}$, and for the $\mathrm{O}: \mathrm{C}$ ratios measured during MASE-II, it should not be used when RH is outside the range $74 \% \leq \mathrm{RH} \leq 92 \%$, or where $\mathrm{VF}_{\text {organic }}$ is less than 0.1 or greater than 0.9 .

\section{Discussion}

Comparing mixed organic-inorganic particles with those comprised entirely of inorganic salts, there is a strong $\mathrm{RH}-$ dependence in the effect of organics on hygroscopicity (Peng et al., 2001). During the MASE-II field campaign, GF values at $74 \% \mathrm{RH}$ averaged $\sim 1.3$. Organic GFs were calculated to be 1.22 at $74 \% \mathrm{RH}$, suggesting that they contributed significantly to overall aerosol water uptake at low RH. GF values at $85 \% \mathrm{RH}$ averaged $\sim 1.6$ during the campaign, and so the organic GF of 1.45 calculated for $85 \%$ RH suggests that organics played a less significant role, but still influenced water uptake at intermediate RH. An organic GF value of 1.48 was calculated for $92 \% \mathrm{RH}$, with DASH-SP $92 \%$ GF measurements of $\sim 1.8$ indicating that organics make little contribution to overall water uptake at high RH.

Inorganic salts exhibit deliquescent behavior as RH is increased. Many organics do not deliquesce or crystallize when $\mathrm{RH}$ is increased or decreased, respectively, but instead retain water at RH values well below the RH of deliquescence (RHD) of the inorganic salts with which they often co-exist in ambient particles. As a result, at $\mathrm{RH}$ values below the salt RHD, the presence of organics enhances water uptake. Thus, the effect of organics is to contribute significantly to overall water uptake at low values of RH in mixed organicinorganic particles. At high RH, on the other hand, organics tend to take up significantly less water than the inorganic constituents with which they co-exist in ambient particles. Therefore, at RH values above the inorganic RHD, organics appear to suppress water uptake relative to that which a pure inorganic particle would exhibit.

Figure 5 shows simplified behavior of a pure ammonium sulfate (AS) particle, pure organic acid (OA) particle (as described by Peng et al., 2001), and a mixed organic acid and ammonium sulfate (OA/AS) particle over the range 
Table 4. GF results for below, above, free troposphere (FT), and ship plume measurements.

\begin{tabular}{|c|c|c|c|c|c|c|c|c|c|c|c|c|}
\hline \multicolumn{13}{|c|}{$150 \mathrm{~nm}$} \\
\hline \multirow[t]{2}{*}{ Flight } & \multicolumn{3}{|c|}{ Below } & \multicolumn{3}{|c|}{ Above } & \multicolumn{3}{|c|}{ FT } & \multicolumn{3}{|c|}{ Ship Plume } \\
\hline & $74 \%$ & $85 \%$ & $92 \%$ & $74 \%$ & $85 \%$ & $92 \%$ & $74 \%$ & $85 \%$ & $92 \%$ & $74 \%$ & $85 \%$ & $92 \%$ \\
\hline 7 & $1.40 \pm 0.04$ & $1.57 \pm 0.03$ & $1.82 \pm 0.05$ & $1.26 \pm 0.06$ & $1.55 \pm 0.04$ & $1.78 \pm 0.01$ & $1.40 \pm 0.03$ & $1.55 \pm 0.03$ & $1.84 \pm 0.04$ & & & \\
\hline 10 & $1.42 \pm 0.04$ & $1.60 \pm 0.06$ & $1.80 \pm 0.04$ & $1.37 \pm 0.10$ & $1.57 \pm 0.04$ & $1.71 \pm 0.11$ & $1.42 \pm 0.03$ & $1.56 \pm 0.04$ & $1.70 \pm 0.07$ & $1.42 \pm 0.04$ & $1.62 \pm 0.03$ & $1.78 \pm 0.04$ \\
\hline 11 & $1.44 \pm 0.05$ & $1.61 \pm 0.06$ & $1.80 \pm 0.07$ & $1.40 \pm 0.07$ & $1.51 \pm 0.02$ & $1.64 \pm 0.05$ & $1.38 \pm 0.07$ & $1.52 \pm 0.06$ & $1.65 \pm 0.10$ & & & \\
\hline 12 & $1.38 \pm 0.03$ & $1.58 \pm 0.03$ & $1.63 \pm 0.04$ & $1.34 \pm 0.04$ & $1.51 \pm 0.03$ & $1.55 \pm 0.01$ & $1.38 \pm 0.02$ & $1.60 \pm 0.01$ & $1.63 \pm 0.01$ & & & \\
\hline 13 & $1.39 \pm 0.01$ & $1.61 \pm 0.05$ & $1.82 \pm 0.02$ & $1.35 \pm 0.01$ & $1.61 \pm 0.03$ & $1.75 \pm 0.05$ & $1.27 \pm 0.05$ & $1.49 \pm 0.07$ & $1.61 \pm 0.08$ & & & \\
\hline 14 & $1.36 \pm 0.05$ & $1.65 \pm 0.21$ & $1.82 \pm 0.14$ & $1.39 \pm 0.02$ & $1.62 \pm 0.01$ & $1.87 \pm 0.09$ & $1.37 \pm 0.03$ & $1.60 \pm 0.03$ & $1.77 \pm 0.06$ & & & \\
\hline 16 & $1.41 \pm 0.02$ & $1.58 \pm 0.05$ & $1.64 \pm 0.08$ & $1.33 \pm 0.03$ & $1.52 \pm 0.03$ & $1.54 \pm 0.03$ & $1.29 \pm 0.04$ & $1.49 \pm 0.07$ & $1.52 \pm 0.06$ & $1.38 \pm 0.02$ & $1.59 \pm 0.02$ & $1.61 \pm 0.04$ \\
\hline \multicolumn{13}{|c|}{$175 \mathrm{~nm}$} \\
\hline Flight & \multicolumn{3}{|c|}{ Below } & \multicolumn{3}{|c|}{ Above } & \multicolumn{3}{|c|}{ FT } & \multicolumn{3}{|c|}{ Ship Plume } \\
\hline & $74 \%$ & $85 \%$ & $92 \%$ & $74 \%$ & $85 \%$ & $92 \%$ & $74 \%$ & $85 \%$ & $92 \%$ & $74 \%$ & $85 \%$ & $92 \%$ \\
\hline 7 & $1.36 \pm 0.06$ & $1.54 \pm 0.02$ & $1.95 \pm 0.03$ & $1.28 \pm 0.04$ & $1.53 \pm 0.03$ & $1.91 \pm 0.06$ & $1.24 \pm 0.08$ & $1.52 \pm 0.03$ & $1.87 \pm 0.10$ & & & \\
\hline 10 & $1.41 \pm 0.06$ & $1.59 \pm 0.05$ & $1.93 \pm 0.02$ & $1.34 \pm 0.05$ & $1.51 \pm 0.01$ & $1.83 \pm 0.06$ & $1.33 \pm 0.02$ & $1.60 \pm 0.03$ & $1.89 \pm 0.05$ & $1.34 \pm 0.02$ & $1.55 \pm 0.05$ & $1.88 \pm 0.06$ \\
\hline 11 & $1.31 \pm 0.08$ & $1.48 \pm 0.07$ & $1.82 \pm 0.09$ & $1.31 \pm 0.03$ & $1.44 \pm 0.09$ & $1.77 \pm 0.03$ & $1.33 \pm 0.04$ & $1.53 \pm 0.12$ & $1.77 \pm 0.23$ & & & \\
\hline 12 & $1.33 \pm 0.02$ & $1.55 \pm 0.04$ & $1.63 \pm 0.08$ & $1.26 \pm 0.06$ & $1.48 \pm 0.08$ & $1.51 \pm 0.07$ & $1.35 \pm 0.02$ & $1.57 \pm 0.01$ & $1.60 \pm 0.01$ & & & \\
\hline 13 & $1.34 \pm 0.03$ & $1.58 \pm 0.04$ & $2.00 \pm 0.05$ & 1.3 & 1.55 & 1.78 & $1.24 \pm 0.05$ & $1.44 \pm 0.06$ & $1.63 \pm 0.10$ & & & \\
\hline 14 & $1.34 \pm 0.01$ & $1.63 \pm 0.02$ & $2.03 \pm 0.01$ & $1.32 \pm 0.02$ & $1.58 \pm 0.02$ & $1.91 \pm 0.05$ & $1.33 \pm 0.02$ & $1.50 \pm 0.08$ & $1.79 \pm 0.22$ & & & \\
\hline 16 & $1.35 \pm 0.04$ & $1.54 \pm 0.03$ & $1.62 \pm 0.06$ & $1.28 \pm 0.02$ & $1.43 \pm 0.04$ & $1.45 \pm 0.04$ & $1.24 \pm 0.04$ & $1.38 \pm 0.06$ & $1.40 \pm 0.10$ & $1.33 \pm 0.03$ & $1.52 \pm 0.04$ & $1.55 \pm 0.03$ \\
\hline \multicolumn{13}{|c|}{$200 \mathrm{~nm}$} \\
\hline Flight & \multicolumn{3}{|c|}{ Below } & \multicolumn{3}{|c|}{ Above } & \multicolumn{3}{|c|}{ FT } & \multicolumn{3}{|c|}{ Ship Plume } \\
\hline & $74 \%$ & $85 \%$ & $92 \%$ & $74 \%$ & $85 \%$ & $92 \%$ & $74 \%$ & $85 \%$ & $92 \%$ & $74 \%$ & $85 \%$ & $92 \%$ \\
\hline 7 & $1.37 \pm 0.04$ & $1.57 \pm 0.03$ & $1.98 \pm 0.03$ & $1.22 \pm 0.06$ & $1.56 \pm 0.05$ & $1.92 \pm 0.01$ & $1.21 \pm 0.01$ & $1.54 \pm 0.08$ & $1.91 \pm 0.04$ & & & \\
\hline 10 & $1.41 \pm 0.09$ & $1.72 \pm 0.09$ & $2.01 \pm 0.05$ & $1.33 \pm 0.02$ & $1.57 \pm 0.07$ & $1.87 \pm 0.04$ & $1.35 \pm 0.01$ & $1.63 \pm 0.06$ & $1.93 \pm 0.06$ & $1.33 \pm 0.04$ & $1.66 \pm 0.06$ & $1.95 \pm 0.05$ \\
\hline 11 & $1.25 \pm 0.11$ & $1.45 \pm 0.17$ & $1.86 \pm 0.07$ & 1.26 & 1.47 & 1.83 & $1.36 \pm 0.16$ & $1.56 \pm 0.15$ & $1.89 \pm 0.20$ & & & \\
\hline 12 & $1.33 \pm 0.03$ & $1.64 \pm 0.03$ & $1.73 \pm 0.05$ & $1.29 \pm 0.03$ & $1.48 \pm 0.10$ & $1.55 \pm 0.12$ & $1.37 \pm 0.05$ & $1.64 \pm 0.05$ & $1.69 \pm 0.04$ & & & \\
\hline 13 & $1.36 \pm 0.05$ & $1.68 \pm 0.05$ & $2.01 \pm 0.04$ & 1.3 & 1.61 & 1.85 & $1.21 \pm 0.08$ & $1.45 \pm 0.07$ & $1.78 \pm 0.12$ & & & \\
\hline 14 & $1.42 \pm 0.11$ & $1.65 \pm 0.05$ & $1.98 \pm 0.10$ & $1.31 \pm 0.05$ & $1.60 \pm 0.03$ & $1.96 \pm 0.01$ & $1.35 \pm 0.09$ & $1.59 \pm 0.10$ & $1.89 \pm 0.11$ & & & \\
\hline 16 & $1.35 \pm 0.02$ & $1.59 \pm 0.05$ & $1.77 \pm 0.08$ & $1.26 \pm 0.02$ & $1.45 \pm 0.08$ & $1.53 \pm 0.10$ & $1.23 \pm 0.06$ & $1.40 \pm 0.10$ & $1.40 \pm 0.11$ & $1.33 \pm 0.03$ & $1.62 \pm 0.04$ & $1.66 \pm 0.06$ \\
\hline
\end{tabular}

$50 \% \leq \mathrm{RH} \leq 94 \%$. Note that the mixed OA/AS particle shows smooth growth with RH, as opposed to the deliquescent behavior exhibited by the pure AS particle. The tendency of organics to retain water at low RH causes water uptake behavior for the OA/AS particle to follow that of the descending (i.e. efflorescence) branch of the pure AS growth curve. Since pure OA takes up less water at high RH than does pure AS, the growth curve for the OA/AS particle is suppressed, compared with that of pure AS. The overall result, as predicted by thermodynamic theory, is that the presence of OA leads to enhanced water uptake at low RH and suppressed GF at high RH.

Virkkula et al. (1999) concluded that the most important factor contributing to GF suppression at high RH was the volume fraction of organic present in an aerosol. Others have suggested that the exact chemical identity of the organic constituents is not especially important, and that for an organic component classified as either oxidized or hydrocarbon-like, its relative abundance determines its effect on GF values (McFiggans et al., 2005; Moore and Raymond, 2008). The aerosol measured during MASE-II was comprised of an internally-mixed combination of highly-oxidized organics with predominantly ammonium bisulfate in the size range $150-200 \mathrm{~nm}$. Results presented here from a stepwise linear regression on GF data from the marine atmosphere suggest that the single most important factor in predicting GF (aside from $\mathrm{RH}$ ) is, indeed, $\mathrm{VF}_{\text {organic }}$. This suggests that an aerosol containing a uniform, highly-oxidized organic component may be sufficiently characterized in global models by a size distribution, $\mathrm{RH}$, and a bulk estimate of the relative abundance of organics.

A brief sensitivity study was undertaken, in order to determine the importance of the $\mathrm{VF}_{\text {organic }}$ term in predicting water uptake for the marine aerosol encountered during this study. Predictions of hygroscopic GF based on the assumption of an entirely inorganic aerosol yielded poorer agreement $\left(R^{2}=0.68\right)$ than the simple parameterization presented in this paper $\left(R^{2}=0.77\right)$. This suggests that accurate predictions of organic volume fraction are important to predict water uptake for a marine aerosol with a uniformly oxidized organic component. 

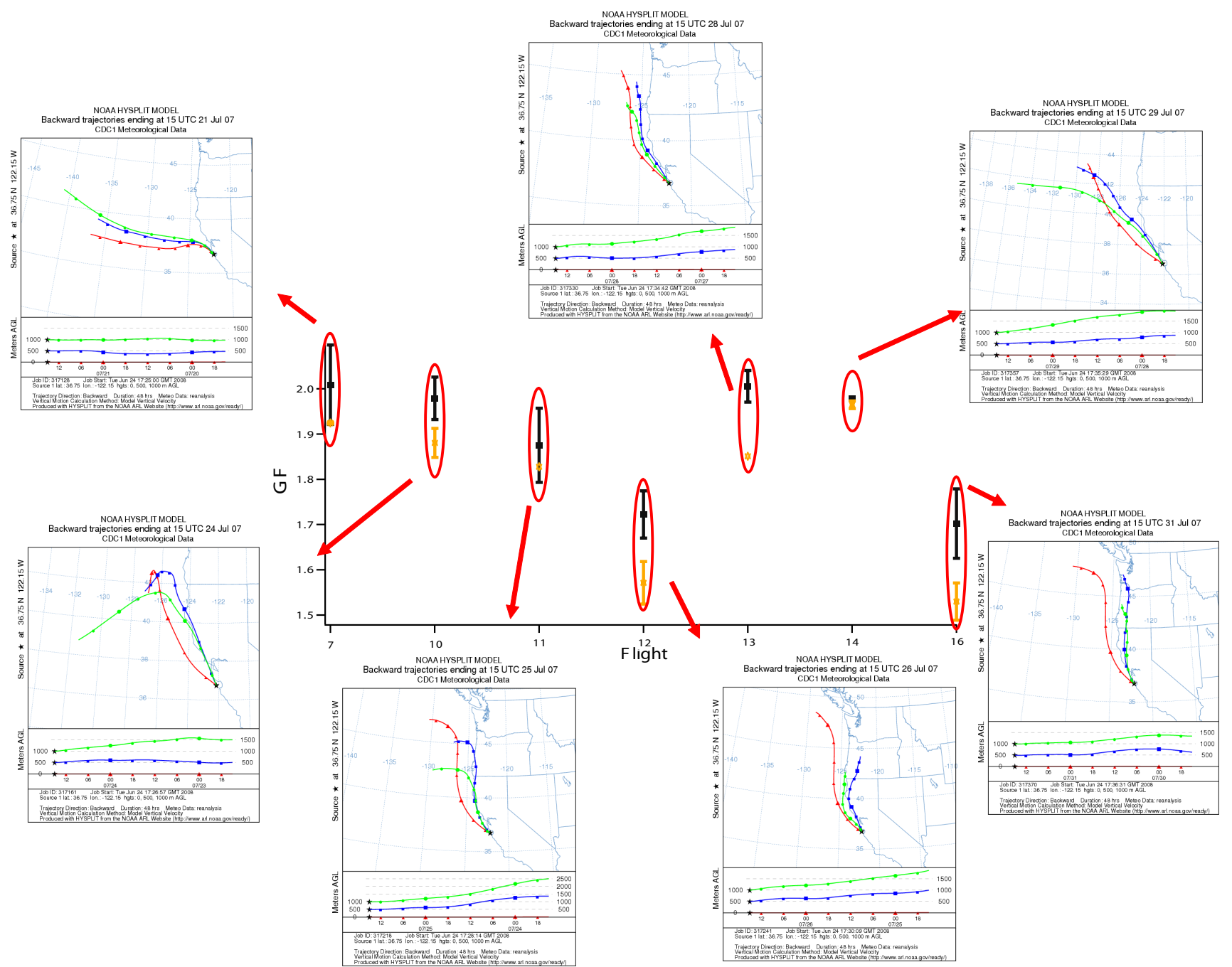

Fig. 1. 92\% GF values for $D_{e m}$, dry $=200 \mathrm{~nm}$ particles are shown for below (black) and above (yellow) cloud flight legs. 48-h HYSPLIT back-trajectories show airmass origin for each flight. Flights 12 and 16 show both suppressed GF values and continental, polluted airmass origin.

In most instruments that measure aerosol hygroscopicity, residence times for humidification are on the order of seconds; much longer than the equilibration time for most inorganics with water vapor. Sjogren et al. (2007) noted, however, that particles with high volume fraction organic material may require as long as $40 \mathrm{~s}$ to achieve equilibrium with water vapor. If such long times are necessary to achieve equilibrium, hygroscopic measurement methods suitable for the field will tend to overpredict GF at low RH (water vapor does not evaporate completely from the particle during the drying process), while underpredicting GF at high RH (insufficient humidification time is provided for the organic fraction to achieve thermodynamic equilibrium with water vapor). In electrodynamic balance (EDB, Cohen et al., 1987a,b,c) studies, suspended particles are subjected to extended exposure to water vapor (minutes to hours), establishing equilibrium.
Some organics exhibit extremely high deliquescence relative humidities (DRH) (e.g., oxalic acid), while others exhibit gradual hygroscopic growth at low RH and substantial growth at high RH (e.g., malonic acid) (Peng et al., 2001). It is possible, given the wide range of organic species in the atmosphere and correspondingly wide range of hygroscopic properties associated with those species, and the relatively short humidification times in the DASH-SP and other similar instruments, that the effects attributed to organics may reflect some kinetic instrumental limitations.

Additionally, while particles entering the DASH-SP are dried to well below relative humidity of efflorescence (RHE) for the inorganic salts encountered in the marine atmosphere, it is possible that the presence of organics causes some particles to remain in a supersaturated (with respect to efflorescence) state after drying. The inorganic fraction of such 


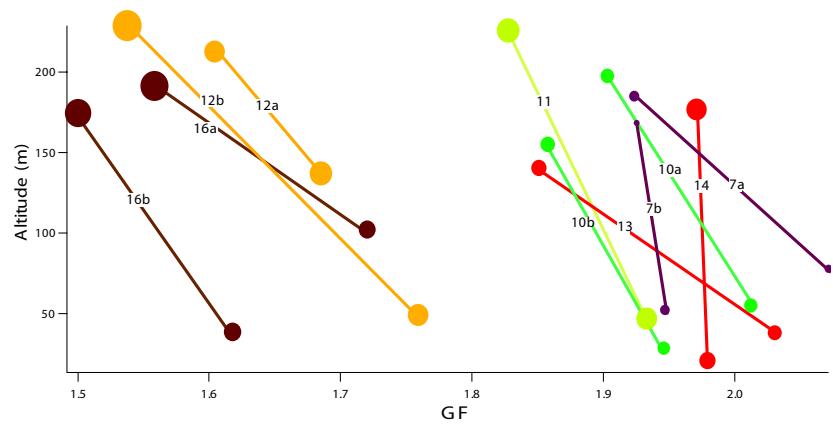

Fig. 2. Below- and above-cloud $92 \%$ GF values for $D_{e m}$, dry 200vnm particles as a function of altitude, with lines connecting measurements made on the same 'trip' from bottom to top of cloud. Marker size is proportional to $\mathrm{VF}_{\text {organic }}$, and ranges from 0.10 to 0.90. "a" and "b" designate separate "trips" during the same flight.

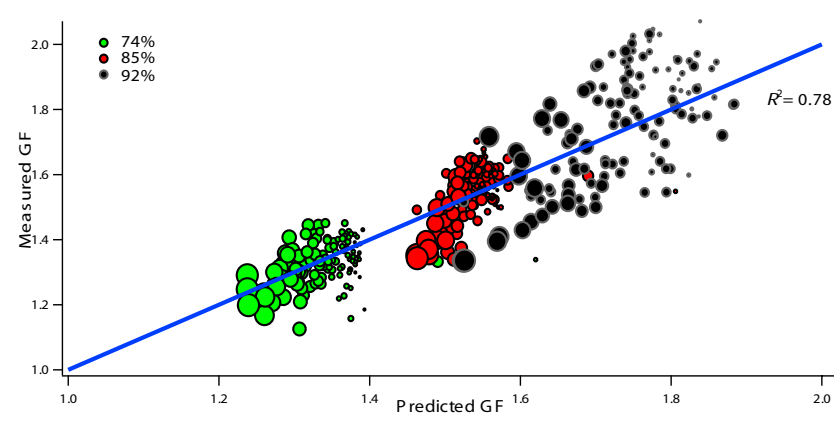

Fig. 3. Measured GF values versus volume-weighted predictions. Markers are color-coded with $\mathrm{RH}$, and marker size is proportional to $\mathrm{VF}_{\text {organic }}$ (ranging from 0.10 to 0.90 ). The blue line represents $1: 1$.

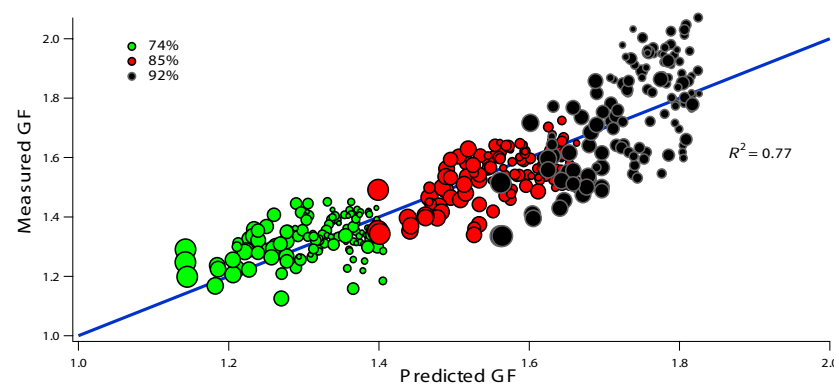

Fig. 4. Predictions of GF from the simplified parameterization. Markers are color-coded with $\mathrm{RH}$, and marker size is proportional to $\mathrm{VF}_{\text {organic }}$ (ranging from 0.10 to 0.90 ). The blue line represents $1: 1$.

a supersaturated particle would exhibit gradual water uptake with increased relative humidity, even at RH lower than the RHD for the inorganic salt. Assuming deliquescent behavior of the inorganic salt (i.e. the inorganic fraction is crystalline at RH RHE), this enhanced water uptake at low RH would be attributed to solely the organic fraction, thereby leading to a potential overestimation in the organic GF.

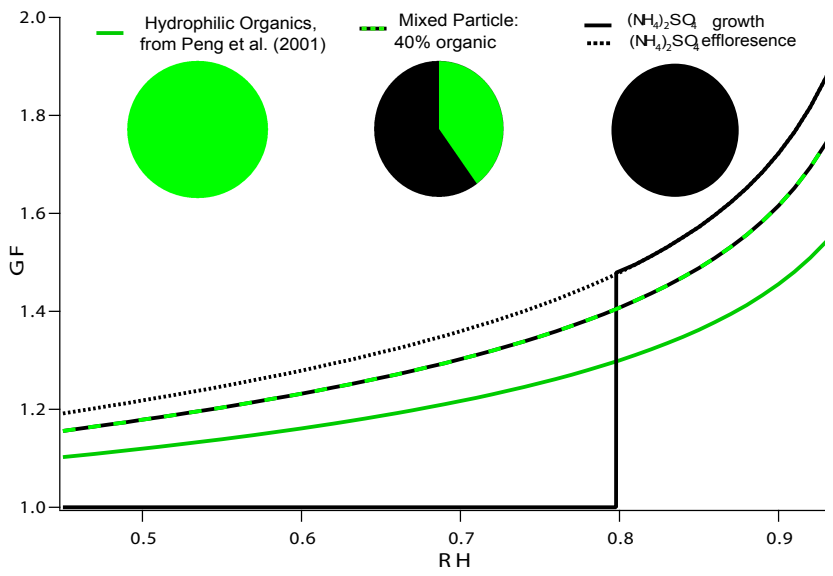

Fig. 5. Comparison of growth curves for pure ammonium sulfate, pure hydrophilic organic, and mixed organic/inorganic particles. Ammonium sulfate curves calculated from AIM (Clegg et al., 1998).

\section{Conclusions}

We report a hygroscopic closure study for the coastal California aerosol, using size-resolved C-ToF-AMS chemical data coupled with highly time-resolved, multiple-RH hygroscopicity measurements from the DASH-SP.

Airmasses originating from continental locations showed elevated organic loading, and correspond to significant GF suppression at high RH. More moderate GF suppression was measured at intermediate RH and no impact was observed at low RH. A comparison of above-cloud with belowcloud aerosol indicated that a slightly organic-enriched layer above cloud corresponded with suppressed GFs at high RH. A volume-weighted hygroscopic closure provided excellent agreement with measured GFs, and mission-averaged organic GFs at 74,85 , and $92 \%$ were calculated to be 1.22 , 1.45 , and 1.48, respectively. These GF values are relatively high when compared with many previous estimations of organic GF, but agree well with values reported for dicarboxylic and multifunctional acids. These high organic GFs are indicative of the highly oxidized state of the aged organic fraction. A simplified parameterization for predicting GF was developed using a stepwise linear regression method. This parameterization is a function of only $\mathrm{RH}$ and $\mathrm{VF}_{\text {organic }}$, and explains only $1 \%$ less variability than does the volume-weighted chemical closure. These results may be more broadly applicable to similar coastal conditions, where some aged organics are present in an otherwise marine-influenced atmosphere.

The richness of this hygroscopic/chemical data set underlies the significance of coupling the DASH-SP instrument with the AMS. The improved time resolution available with the DASH-SP eliminates much of the time-averaging of AMS composition data that is otherwise necessary with less highly time-resolved HTDMA hygroscopicity measure- 
ments. The importance of simultaneous GF measurements at multiple $\mathrm{RH}$ values is demonstrated by a simplified parameterization for predicting $\mathrm{GF}$ as a function of $\mathrm{RH}$ and $\mathrm{VF}_{\text {organic }}$; a result potentially important for efficiently representing aerosol-water interactions in global models.

Acknowledgements. This work was supported by the Office of Naval Research grant N00014-04-1-0118. We acknowledge the committed, meticulous work of the CIRPAS Twin Otter crew, especially pilot Mike Hubbell and copilot Chris McGuire.

Edited by: A. Nenes

\section{References}

Aiken, A. C., DeCarlo, P. F., Kroll, J., Worsnop, D., J.A., H., Docherty, K., Ulbrich, I., Mohr, C., Kimmel, J., Sueper, D., Sun, Y., Zhang, Q., Trimborn, A., Northway, M., Ziemann, P., Canagaratna, M., Onsach, T., Alfarra, M., Prevot, A., Dommen, J., Duplissy, J., Metzger, A., Baltensperger, U., and Jimenez, J. L.: O/C and OM/OC Ratios of Primary, Secondary, and Ambient Organic Aerosols with High-Resolution Time-of-Flight Aerosol Mass Spectrometry, Environ. Sci. Technol., 42, 44784485, 2008.

Allan, J., Bower, K., Alfarra, M., Delia, A., Jimenez, J., Middlebrook, A., Drewnick, F., Onasch, T., Canagaratna, M., Jayne, J., and Worsnop, D.: Technical note: Extraction of Chemically Resolved Mass Spectra from Aerodyne Aerosol Mass Spectrometer Data, J. Aerosol Sci., 35, 909-922, 2004.

Ansari, A. S. and Pandis, S. N.: Water absorption by secondary organic aerosol and its effect an inorganic aerosol behavior, Environ. Sci. Technol., 34, 71-77, 2000.

Berg, O. H., Swietlicki, E., and Krejci, R.: Hygroscopic growth of aerosol particles in the marine boundary layer over the $\mathrm{Pa}$ cific and Southern Oceans during the First Aerosol Characterization Experiment (ACE 1), J. Geophys. Res., 103, 16 535-16545, 1998.

Carrico, C. M., Rood, M. J., and Ogren, J. A.: Aerosol light scattering properties at Cape Grim, Tasmania, during the First Aerosol Characterization Experiment (ACE 1), J. Geophys. Res., 103, 16565-16574, 1998.

Carrico, C. M., Rood, M. J., Ogren, J. A., Neususs, C., Wiedensohler, A., and Heintzenberg, J.: Aerosol optical properties at Sagres, Portugal during ACE-2, Tellus B, 52, 694-715, 2000.

Choi, M. Y. and Chan, C. K.: Continuous measurements of the water activities of aqueous droplets of water-soluble organic compounds, J. Phys. Chem. A, 106, 4566-4572, 2002a.

Choi, M. Y. and Chan, C. K.: The effects of organic species on the hygroscopic behaviors of inorganic aerosols, Environ. Sci. Technol., 36, 2422-2428, 2002 b.

Clegg, S. L. and Seinfeld, J. H.: Thermodynamic models of aqueous solutions containing inorganic electrolytes and dicarboxylic acids at 298.15 K. 2. Systems including dissociation equilibria, J. Phys. Chem. A, 110, 5718-5734, 2006.

Clegg, S. L., Brimblecombe, P., and Wexler, A. S.: Thermodynamic model of the system $\mathrm{H}^{+}-\mathrm{NH}_{4}^{+}-\mathrm{SO}_{4}^{2-}-\mathrm{NO}_{3}^{-}-\mathrm{H}_{2} \mathrm{O}$ at tropospheric temperatures, J. Phys. Chem. A, 102(12), 2137-2154, 1998.
Cocker, D. R., Clegg, S. L., Flagan, R. C., and Seinfeld, J. H.: The effect of water on gas-particle partitioning of secondary organic aerosol. Part I: alpha-pinene/ozone system, Atmos. Environ., 35, 6049-6072, 2001a.

Cocker, D. R., Mader, B. T., Kalberer, M., Flagan, R. C., and Seinfeld, J. H.: The effect of water on gas-particle partitioning of secondary organic aerosol: II. m-xylene and 1,3,5trimethylbenzene photooxidation systems, Atmos. Environ., 35, 6073-6085, 2001b.

Cohen, M. D., Flagan, R. C., and Seinfeld, J. H.: Studies of concentrated electrolyte-solutions using the electrodynamic balance. 1. Water activities for single-electrolyte solutions, J. Phys. Chem., 91, 4563-4574, 1987a.

Cohen, M. D., Flagan, R. C., and Seinfeld, J. H.: Studies of concentrated electrolyte-solutions using the electrodynamic balance. 2 . Water activities for mixed-electrolyte solutions, J. Phys. Chem., 91, 4575-4582, 1987b.

Cohen, M. D., Flagan, R. C., and Seinfeld, J. H.: Studies of concentrated electrolyte-solutions using the electrodynamic balance. 3 . Solute nucleation, J. Phys. Chem., 91, 4583-4590, 1987c.

Cruz, C. N. and Pandis, S. N.: Deliquescence and hygroscopic growth of mixed inorganic-organic atmospheric aerosol, Environ. Sci. Technol., 34, 4313-4319, 2000.

DeCarlo, P., Slowik, J., Worsnop, D., Davidovits, P., and Jimenez, J.: Particle Morphology and Density Characterization by Combined Mobility and Aerodynamic Diameter Measurements. Part 1: Theory, Aerosol. Sci. Tech., 39, 1185-1205, 2004.

Dougle, P. G., Veefkind, J. P., and ten Brink, H. M.: Crystallisation of mixtures of ammonium nitrate, ammonium sulphate and soot, J. Aerosol Sci., 29, 375-386, 1998.

Drewnick, F., Jayne, J. T., Canagaratna, M., Worsnop, D. R., and Demerjian, K. L.: Measurement of ambient aerosol composition during the PMTACS-NY 2001 using an aerosol mass spectrometer. Part II: Chemically speciated mass distributions, Aerosol. Sci. Tech., 38, 104-117, suppl. 1, 2004a.

Drewnick, F., Schwab, J. J., Jayne, J. T., Canagaratna, M., Worsnop, D. R., and Demerjian, K. L.: Measurement of ambient aerosol composition during the PMTACS-NY 2001 using an aerosol mass spectrometer. Part I: Mass concentrations, Aerosol. Sci. Tech., 38, 92-103, suppl. 1, 2004b.

Duplissy, J., Gysel, M., Alfarra, M. R., Dommen, J., Metzger, A., Prevot, A. S. H., Weingartner, E., Laaksonen, A., Raatikainen, T., Good, N., Turner, S. F., McFiggans, G., and Baltensperger, U.: Cloud forming potential of secondary organic aerosol under near atmospheric conditions, Geophys. Res. Lett., 35, L03818, doi:10.1029/2007GL031075, 2008.

Gasso, S., Hegg, D. A., Covert, D. S., Collins, D., Noone, K. J., Ostrom, E., Schmid, B., Russell, P. B., Livingston, J. M., Durkee, P. A., and Jonsson, H.: Influence of humidity on the aerosol scattering coefficient and its effect on the upwelling radiance during ACE-2, Tellus B, 52(2), 546-567, 2000.

Gysel, M., Crosier, J., Topping, D. O., Whitehead, J. D., Bower, K. N., Cubison, M. J., Williams, P. I., Flynn, M. J., McFiggans, G. B., and Coe, H.: Closure study between chemical composition and hygroscopic growth of aerosol particles during TORCH2, Atmos. Chem. Phys., 7, 6131-6144, 2007, http://www.atmos-chem-phys.net/7/6131/2007/.

Hameri, K., Charlson, R., and Hansson, H. C.: Hygroscopic properties of mixed ammonium sulfate and carboxylic acids particles, 
AIChE J., 48, 1309-1316, 2002.

Hegg, D. A., Covert, D. S., Rood, M. J., and Hobbs, P. V.: Measurements of aerosol optical properties in marine air, J. Geophys. Res., 101, 12 893-12 903, 1996.

Hegg, D. A., Covert, D. S., Crahan, K., and Jonssen, H.: The dependence of aerosol light-scattering on RH over the Pacific Ocean, Geophys. Res. Lett., 29, 60-4, 2002.

Hegg, D. A., Covert, D. S., Crahan, K. K., Jonsson, H. H., and Liu, Y.: Measurements of aerosol size-resolved hygroscopicity at sub and supermicron sizes, Geophys. Res. Lett., 33, L21808, doi:10.1029/2006GL026747, 2006.

Huffman, J., Jayne, J., Drewnick, F., Aiken, A., Onasch, T., Worsnop, D., and Jimenez, J.: Design, modeling, optimization, and experimental tests of a particle beam width probe for the aerodyne aerosol mass spectrometer, J. Aerosol Sci., 38, 11431163,2005

IPCC: Climate Change 2007: The Physical Science Basis. Contribution of Working Group I to the Fourth Assessment Report of the Intergovernmental Panel on Climate Change, Cambridge University Press, Cambridge, United Kingdom and New York, NY, USA, 153-180, 2007.

Kaku, K. C., Hegg, D. A., Covert, D. S., Santarpia, J. L., Jonsson, H., Buzorius, G., and Collins, D. R.: Organics in the Northeastern Pacific and their impacts on aerosol hygroscopicity in the subsaturated and supersaturated regimes, Atmos. Chem. Phys., 6, 4101-4115, 2006, http://www.atmos-chem-phys.net/6/4101/2006/.

Kasten, F.: Visibility forecast in phase of pre-condensation, Tellus, 21(5), 631-635, 1969.

Kim, J., Yoon, S. C., Jefferson, A., and Kim, S. W.: Aerosol hygroscopic properties during Asian dust, pollution, and biomass burning episodes at Gosan, Korea in April 2001, Atmos. Environ., 40, 1550-1560, 2006.

Kondo, Y., Miyazaki, Y., Takegawa, N., Miyakawa, T., Weber, R. J., Jimenez, J. L., Zhang, Q., and Worsnop, D. R.: Oxygenated and water-soluble organic aerosols in Tokyo, J. Geophys. Res., 112, D01203, doi:10.1029/2006JD007056, 2007.

Kreisberg, N. M., Stolzenburg, M. R., Hering, S. V., Dick, W. D., and McMurry, P. H.: A new method for measuring the dependence of particle size distributions on relative humidity, with application to the Southeastern Aerosol and Visibility Study, J. Geophys. Res., 106, 14935-14 949, 2001.

Lu, M. L., Conant, W. C., Jonsson, H. H., Varutbangkul, V., Flagan, R. C., and Seinfeld, J. H.: The Marine Stratus/Stratocumulus Experiment (MASE): Aerosol-cloud relationships in marine stratocumulus, J. Geophys. Res., 112, D10209, doi:10.1029/2006JD007985, 2007.

Magi, B. I. and Hobbs, P. V.: Effects of humidity on aerosols in southern Africa during the biomass burning season, J. Geophys. Res., 108, 8495, doi:10.1029/2002JD002144, 2003.

Malm, W. C., Day, D. E., Kreidenweis, S. M., Collett, J. L., Carrico, C., McMeeking, G., and Lee, T.: Hygroscopic properties of an organic-laden aerosol, Atmos. Environ., 39, 4969-4982, 2005.

Massling, A., Leinert, S., Wiedensohler, A., and Covert, D.: Hygroscopic growth of sub-micrometer and one-micrometer aerosol particles measured during ACE-Asia, Atmos. Chem. Phys., 7, 3249-3259, 2007,

http://www.atmos-chem-phys.net/7/3249/2007/.
Massling, A., Wiedensohler, A., Busch, B., Neusüß, C., Quinn, P., Bates, T., and Covert, D.: Hygroscopic properties of different aerosol types over the Atlantic and Indian Oceans, Atmos. Chem. Phys., 3, 1377-1397, 2003,

http://www.atmos-chem-phys.net/3/1377/2003/.

McFiggans, G., Alfarra, M. R., Allan, J., Bower, K., Coe, H., Cubison, M., Topping, D., Williams, P., Decesari, S., Facchini, C., and Fuzzi, S.: Simplification of the representation of the organic component of atmospheric particulates, Faraday Discuss., 130, 341-362, 2005.

Moore, R. H. and Raymond, T. M.: HTDMA analysis of multicomponent dicarboxylic acid aerosols with comparison to UNIFAC and ZSR, J. Geophys. Res., 113, D04206, doi:10.1029/2007JD008660, 2008.

Murphy, S., Agrawal, H., Sorooshian, A., Padaro, L., Gates, H., Hersey, S., Welch, W., Jung, H., Miller, J., Cocker, D., Nenes, A., Jonsson, H., Flagan, R., and Seinfeld, J.: Comprehensive Simultaneous Shipboard and Airborne Characterization of Exhaust from a Modern Container Ship at Sea, Environmen. Sci. Technol., doi:10.1021/es802413j, published online: http://pubs.acs. org/doi/abs/10.1021/es802413j, 2009

Peng, C., Chan, M. N., and Chan, C. K.: The hygroscopic properties of dicarboxylic and multifunctional acids: Measurements and UNIFAC predictions, Environ. Sci. Technol., 35, 4495-4501, 2001.

Peng, C. G. and Chan, C. K.: The water cycles of water-soluble organic salts of atmospheric importance, Atmos. Environ., 35, 1183-1192, 2001

Petters, M. D., Kreidenweis, S. M., Snider, J. R., Koehler, K. A., Wang, Q., Prenni, A. J., and Demott, P. J.: Cloud droplet activation of polymerized organic aerosol, Tellus B, 58, 196-205, 2006.

Prenni, A. J., DeMott, P. J., Kreidenweis, S. M., Sherman, D. E., Russell, L. M., and Ming, Y.: The effects of low molecular weight dicarboxylic acids on cloud formation, J. Phys. Chem. A, 105, 11240-11248, 2001.

Prenni, A. J., De Mott, P. J., and Kreidenweis, S. M.: Water uptake of internally mixed particles containing ammonium sulfate and dicarboxylic acids, Atmos. Environ., 37, 4243-4251, 2003.

Prenni, A. J., Petters, M. D., Kreidenweis, S. M., DeMott, P. J., and Ziemann, P. J.: Cloud droplet activation of secondary organic aerosol, J. Geophys. Res., 112, D10223, doi:10.1029/2006JD007963, 2007.

Rood, M. J., Larson, T. V., Covert, D. S., and Ahlquist, N. C.: Measurement of laboratory and ambient aerosols with temperature and humidity controlled nephlometry, Atmos. Environ., 19, 1181-1190, 1985.

Saathoff, H., Naumann, K. H., Schnaiter, M., Schock, W., Mohler, O., Schurath, U., Weingartner, E., Gysel, M., and Baltensperger, $\mathrm{U}$.: Coating of soot and $\left(\mathrm{NH}_{4}\right)_{2} \mathrm{SO}_{4}$ particles by ozonolysis products of alpha-pinene, J. Aerosol Sci., 34, 1297-1321, 2003.

Seinfeld, J. and Pandis, S.: Atmospheric Chemistry and Physics, Wiley-Interscience, New York, NY, USA, 2nd edn., 2006.

Sjogren, S., Gysel, M., Weingartner, E., Baltensperger, U., Cubison, M. J., Coe, H., Zardini, A. A., Marcolli, C., Krieger, U. K., and Peter, T.: Hygroscopic growth and water uptake kinetics of twophase aerosol particles consisting of ammonium sulfate, adipic and humic acid mixtures, J. Aerosol Sci., 38, 157-171, 2007. 
Sorooshian, A., Hersey, S., Brechtel, F., Corless, A., Flagan, R., and Seinfeld, J.: Rapid, Size-Resolved Aerosol Hygroscopic Growth Measurements: Differential Aerosol Sizing and Hygroscopicity Spectrometer Probe (DASH-SP), Aerosol. Sci. Tech., 42, 445464, 2008a.

Sorooshian, A., Murphy, S. M., Hersey, S., Gates, H., Padro, L. T., Nenes, A., Brechtel, F. J., Jonsson, H., Flagan, R. C., and Seinfeld, J. H.: Comprehensive airborne characterization of aerosol from a major bovine source, Atmos. Chem. Phys., 8, 5489-5520, $2008 b$.

Swietlicki, E., Zhou, J. C., Covert, D. S., Hameri, K., Busch, B., Vakeva, M., Dusek, U., Berg, O. H., Wiedensohler, A., Aalto, P., Makela, J., Martinsson, B. G., Papaspiropoulos, G., Mentes, B., Frank, G., and Stratmann, F.: Hygroscopic properties of aerosol particles in the northeastern Atlantic during ACE-2, Tellus B, 52, 201-227, 2000.

Tomlinson, J. M., Li, R. J., and Collins, D. R.: Physical and chemical properties of the aerosol within the southeastern Pacific marine boundary layer, J. Geophys. Res., 112, 1-13, 2007.

Topping, D. O., McFiggans, G. B., and Coe, H.: A curved multicomponent aerosol hygroscopicity model framework: Part 1 - Inorganic compounds, Atmos. Chem. Phys., 5, 1205-1222, 2005a.
Topping, D. O., McFiggans, G. B., and Coe, H.: A curved multicomponent aerosol hygroscopicity model framework: Part 2 Including organic compounds, Atmos. Chem. Phys., 5, 1223 1242, 2005b.

Vakeva, M., Hameri, K., and Aalto, P. P.: Hygroscopic properties of nucleation mode and Aitken mode particles during nucleation bursts and in background air, J. Geophys. Res., 107(D19), PAR91-11, 2002.

Varutbangkul, V., Brechtel, F. J., Bahreini, R., Ng, N. L., Keywood, M. D., Kroll, J. H., Flagan, R. C., Seinfeld, J. H., Lee, A., and Goldstein, A. H.: Hygroscopicity of secondary organic aerosols formed by oxidation of cycloalkenes, monoterpenes, sesquiterpenes, and related compounds, Atmos. Chem. Phys., 6, 23672388, 2006, http://www.atmos-chem-phys.net/6/2367/2006/.

Virkkula, A., Van Dingenen, R., Raes, F., and Hjorth, J.: Hygroscopic properties of aerosol formed by oxidation of limonene, alpha-pinene, and beta-pinene, J. Geophys. Res., 104, 3569 3579, 1999.

Zhou, J. C., Swietlicki, E., Berg, O. H., Aalto, P. P., Hameri, K., Nilsson, E. D., and Leck, C.: Hygroscopic properties of aerosol particles over the central Arctic Ocean during summer, J. Geophys. Res., 106, 32 111-32 123, 2001. 